\title{
Improved Ass? Apuleius' Metamorphoses in His Novel Metamorphoses
}

\author{
Katarina Petrovićová \& Natália Gachallová \\ (Masaryk University, Brno)
}

\begin{abstract}
Apuleius' novel Metamorphoses has always been open to various and often contradictory interpretations by scholars. One of the most discussed issues has been the novel's division into two seemingly dissimilar parts - the first ten books containing frivolous stories with comical elements and Book XI (also called the Isis-Book) written in a more serious tone and considered to be conveying a religious or, at least, moral message. The authors of the present paper argue against such a simplified assumption and regard the dividing line between the two parts as a mere illusion. This opinion derives from the figure of the main protagonist, Lucius, who in the last book undergoes a religious initiation into the cult of Isis. The aim of the paper is to show that, although he is finally re-transformed into human shape and even lives a prosperous life afterwards, inside he undergoes no inner change whatsoever and remains the same "ass" as in the beginning of the story, i.e. he is not improved in the end. This rules out the possibility that the novel conveyed any deeper religious message and rather points to another interpretation, namely that Apuleius wrote the novel for an educated readership in the spirit of Platonic dialogues. The authors are therefore convinced that the novel can be fully enjoyed only after a scrupulous and thoughtful reading.
\end{abstract}

\section{Keywords}

Apuleius; Metamorphoses; transformation; curiositas; ass' amendment; lector scrupulosus; Isis-Book; elite readership

The Metamorphoses of Apuleius is a literary work which, despite the huge interest of literary historians and critics, still raises multiple questions and doubts with no definite answers. This only completely preserved Roman novel has been characterised as a realistic satire or a parody, but also as a novel conveying a deep religious message whose realism is seen as a mere preparation for the idealistic outfall. The reason for these contradicting assessments is that the novel seems to disintegrate into two seemingly inconsistent parts. In the first ten books, a noble handsome and, especially, a dangerously curious young man from Corinth (Met. 1,22,3; 2,12,2) named Lucius narrates his adventurous and unusual peregrination starting in Hypatae, a town known for its magical practices. 
He is accidentally transformed into an ass and, as such, he experiences and hears of various misfortunes. In the last eleventh book, Lucius is finally set free from his ass form to undergo a ritual initiation. Unlike the Greek version of the story, Apuleius' Book XI introduces an innovative outcome. After the transformation, the Greek Loukios wants to continue in his frolic with the lady whom he used to have sexual intercourse with while being an ass, whereas the Latin Lucius gives himself fully to goddess Isis as a renatus ("reborn", see Met. 11,16,12 and 11,21,12; cf. also 11,14,20) and finally even becomes Osiris' pastophorus.

The aim of this paper is to find answers to the questions whether and what transformations take place in the novel and what consequences do these changes have for the general interpretation of the novel. Answering these, we pursue to argue for the novel's unity and to display its well-thought-out coherence. The focus is put on the physical transformation of a human into an ass and on what is going on inside the transformed hero as well as on the turning points in the narrative.

The outward transformation of Lucius taking place on the level of event description is fully objective. His physiognomy is distinguished by universal symmetry, ie. Lucius countenance and body are "agreeing in each point" (2,2,4: ... sanctissimae Salviae matris generosa probitas, sed et cetera corporis exsecrabiliter ad amussim congruentia: ${ }^{1}$ inenormis proceritas, suculenta gracilitas, rubor temperatus, flavum et inadfectatum capillitium, oculi caesii quidem, sed vigiles et in aspectu micantes, prorsus aquilini, os quoquoversum floridum, speciosus et immeditatus incessus). People around him base their assumptions regarding his exquisite character (generosa probitas) and noble origin (1,2,1; 2,3,3; and especially 3,11,1:... neque tuae dignitatis vel etiam prosapiae tuorum ignari sumus, Luci domine; nam et provinciam totam inclitae vestrae familiae nobilitas complectitur $)^{2}$ exclusively on his physical beauty, as it is common in the Antonine literary depictions. ${ }^{3}$ The general popularity of physiognomic studies in the age of the Antonines is attested e.g. by Polemo of Laodicea's treatise called De Physiognomonia. ${ }^{4}$ What is more, the depictions of Lucius' prettiness in Metamorphoses are strikingly similar to those stated in physiognomic studies of the time, which is clear from the (probably not randomly)

1 The relevant phrases of the cited passages of Metamorphoses are highlighted in bold throughout the whole paper to clarify the authors' arguments. For the sake of accuracy, we cite the exact lines according to the edition of Rudolf Helm (2001).

2 Some scholars put this in association with Apuleius' description of his own origin in Apul. Apol. 24: ... splendidissima colonia sumus, in qua colonia patrem habui loco principis II viralem cunctis honoribus perfunctum. Cf. also the criticism of Apuleius' nice appearance as inappropriate for a philosopher in Apul. Apol. 4.5.4: accusamus apud te philosophum formonsum. Nevertheless, the identification of Apuleius with the main protagonist of his novel is very problematic; see further in this study.

3 See Keulen (2006: p. 170). For the emphasis on good proportions and their harmony, see Ps.-Arist. 814a; for sparkling eyes as a sign of intelligence, see Ps.-Arist. 812b. Descriptions of the main protagonists of Greek novels are also in agreement with these (see e.g. Ach. Tat. 1.4.3.; Xen. Eph. 1.2.5). For the detailed examination of the general popularity of physiognomic studies in this age, including Apuleius, see Evans (1941: especially pp. 103 f.).

4 Unfortunately, the original work in Greek did not preserve; however, it exists in the $14^{\text {th }}$ century Arabic translation. This paper works with the Latin translation of Arabic text by Georg Hoffmann accessible in R. Foerster (Ed.), Scriptores Physiognomonici Graeci et Latini (Vol. 1, pp. 98-294, Leipzig: Teubner). Further on, the work will be cited only as Polem. Phgn. including the exact page in Foerster's edition. Cf. also Swain (2007: pp. 125-201). 
parallel passages. ${ }^{5}$ Lucius' physical beauty is, furthermore, repeatedly confirmed by the references to his kinship with Plutarch, the noble philosopher $(1,2,1$ : ... originis maternae fundamenta a Plutarcho illo ac mox Sexto nepote eius prodita gloriam nobis faciunt; 2,3,3: Byrrhena's (Lucius' aunt) speech: ... Plutarchi familia ambae (ie. et Lucii mater et Byrrhena) prognatae sumus...). The more beautiful Lucius is as a man, the more hideous he looks as an ass. Incongruity and deviation from the norm are what defines his outward image - e.g. outstanding ears, big teeth, bloated lips, disproportional legs, and giant genitals. Apuleius stresses the ass' physical deformity three times altogether: twice when describing the very transformation of a man into an ass and vice-versa (3,24,2 f.; 11,13,3 $)^{6}$ and once when Lucius becomes the object of zoophile desire of certain noble lady and abhors that his above-standard proportions might hurt her during sexual intercourse (10,22,1: Sed angebar plane non exili metu reputans, quem ad modum tantis tamque magis cruribus possem delicatam matronam inscendere ... quo pacto, ..., mulier tam vastum genitale susciperet...). The latter displays a discrepancy in the narrative, which impugns the transformation on the subjective level. Here, Lucius assesses his physical apparatus negatively, whereas right after the transformation he regarded it the only advantage of his new shape $(3,24,3$ : cf. note 6$)$. This is the first evidence of the contrast between the certainty of Lucius' outward change and the ambiguousness and disarray of Lucius' subjective feelings throughout the narrative.

Before any further analysis, another issue must be noted, as it, although inconspicuously, pertains to the abovementioned passage regarding physical appearance. Lucius' shape is described as "damn", or rather "damnably" (exsecrabiliter), beautiful. This is, no doubt, a wittingly revealed indication of the future events, one of Apuleius' insights into the depths of the novel. As will be shown later, Apuleius both deliberately obscures the unambiguous comprehension of the events taking place and, at the same time, provides an attentive reader with various hints guiding him through the story. ${ }^{7}$ However, let us now get back to the analysis of the metamorphoses.

5 Cf. Ps.-Polem. Physiogn. 5 (Foerster, vol. 2: p. 151); Anonymi de Physiognomonia liber 79 (Foerster, vol. 2: p. 107). Moreover, there is a remarkable similarity between Lucius' appearance and Polemo's description of a "pure" Greek in Polem. Phgn. 35 (Foerster vol. 1: p. 242: De Graecis et eorum genere puro): Est autem purus Graecus moderatae inter longam et brevem, latam et angustam staturae et erectae, plucrae faciei et vultus, coloris albi rubedine mixti, mediocriter carnosus moderatis manibus et cubitis praeditus, vigil celeriter discens... oculi umidi charopi valde mobiles multum luminis continentes. Note also the similarity of this with Polemo's image of litteratus in Polem. Phgn. 55 (Foerster vol. 1: p. 272: De viro litterarum amante et eius signis).

6 The parallel structure of both passages is striking: cf. Apul. Met. 3,24,2 f.: ... plane pili mei crassantur in setas et cutis tenella duratur in corium et in extimis palmulis perdito numero toti digiti coguntur in singulas ungulas et de spinae meae termino grandis cauda procedit. Iam facies enormis et os prolixum et nares hiantes et labiae pendulae; sic et aures inmodicis horripilant auctibus. Nec ullum miserae reformationis video solacium, nisi quod mihi iam nequeunti tenere Photidem natura crescebat; and 11,13,3: ... protinus mihi delabitur deformis et ferina facies. Ac primo quidem squalens pilus defluit, ac dehinc cutis crassa tenuatur, venter obesus residet, pedum plantae per ungulas in digitos exeunt, manus non iam pedes sunt, sed in erecta porriguntur officia, cervix procera cohibetur, os et caput rutundatur, aures enormes repetunt pristinam parvitatem, dentes saxei redeunt ad humanam minutiem, et, quae me potissimum cruciabat ante, cauda nusquam!

7 We do not concur with the view of Smith who claims that the essential feature of Apuleius' narrative method is the deception of reader's expectations. See Smith (1972: p. 527). The story does not flow trivially; on the contrary, the reader is provided with clues demanding a careful reading. If the reader manages to untangle these, he cannot be disappointed in the end. 
Another notion which objectively changes in the narrative is Lucius' geographical origin. The reader is informed by two references in Book I and II that Lucius comes from Corinth $(1,22,3 ; 2,12,2)^{8}$ but, in the last book, the priest addresses Lucius as Madaurensis, i.e. with Apuleius' own identity, informing Lucius about the fact that he has already been acquainted with the arrival of a man from Madauros (11,27,9: nam sibi visus est quiete proxima, dum magno deo coronas exaptat, *** et de eius ore, quo singulorum fata dictat, audisse mitti sibi Madaurensem, sed admodum pauperem, sui statim sua sacra deberet ministrare; nam et illi studiorum gloriam et ipsi grande compendium sua comparari providentia).

Perry's interpretation ${ }^{9}$ of this as Apuleius' mistake or inability to unify the novel has been refuted by the majority of scholars. Recently, the prevailing view is that the reference to Madaurensis serves Apuleius to identify himself with the transformed Lucius, which shifts the obscene novel narrative towards a personal testimony of religious initiation, ${ }^{10}$ or to picture in this symbolic way Lucius' metamorphosis as a transgression from the comic parody of the Greek model to the Roman variation on the topic. ${ }^{11}$

Both courses of interpretation, however, imply a supposed disruption between Book I-X and Book XI. Harrison has come with a more natural explanation of the above-said incongruity. He bases his interpretation on passage 4,32,6 in which Apollo, quamquam Graecus et Ionicus, speaks Latin (sic Latina sorte respondit) with respect to huius Milesiae conditorem (while the original story has been narrated in Greek). ${ }^{12}$ This is a place where Apuleius intervenes in the old wife's tale of Amor and Psyche. The epithet Madaurensis is used in a similar way; however, according to Harrison, not as a narrative metalepsis (as in the Book IV) but as a metonymy referring to Apuleius' book which underlies its fictional character as well as author's play with the expectations of his readers. ${ }^{13}$ At the same time, it can be supposed that Apuleius reveals his identity and alludes to his hometown

8 Apul. Met. 1,22,3: ... litteras ei a Corinthio Demea scriptas ad eum reddo... (Lucius speaks to a maid on the doorstep, asks for hospitality, and refers to the recommendation from his fellow-countryman); 2,12,2: ... nam et Corinthi nunc apud nos passim Chaldaeus quidam hospes miris totam civitatem responsis turbulentat... (Lucius shares his experiences from his native town at a dining table).

9 Perry (1967: p. 240). This objection was present in the interpretations of Apuleius right from the start of modern studies on him: see also e.g. Oudendorp (1786: p. 812): "Turpiter vero hic sui oblitus est Appulejus."

10 I.e. the story is approached from the autobiographical or partially autobiographical point of view. This attitude was advocated already by Augustine in his Civ. 18.18 and, later on, held again and again by scholars of all periods of modern Classical Philology; see e.g. Hildebrand (1842: p. xix); Rohde (1885: pp. 77 f.); Wittmann (1938: pp. 122 f.); Griffiths (1975: p. 5); Tatum (1982: pp. 1112 f.); Coarelli (1989: p. 40); Finkelpearl (2004: pp. 333-335), etc.

11 See e.g. Winkler (1985) who assumes that the change of tone in Book XI is a symbolic reflection of Lucius' own metamorphosis. See also another variation of this interpretation in Groningen Commentaries on Apuleius (further only GCA) XI (2015: p. 31), namely the idea that, with the end of Book X, the novel's pathos changes from the Greek Odyssean peregrination towards the Roman style of the Aeneid. This is paralleled by the shift from the periphery towards the centre in Book XI. For the complete list of the interpretative approaches of scholars in the past and nowadays, see GCA XI (2015: pp. 465-467).

12 The passage is very likely an intertextual allusion to Cic. Div. 2.116: ... Latine Apollo numquam locutus est..., which well agrees with Apuleius' playful approach to his readership; see GCA IV 28-35, V, VI 1-24 (2004: p. 85).

13 Osiris predicts that the priest Asinius is to become a literary figure of the novel written by some Madaurensis. See Harrison (2000: pp. 230 f.). Harrison revealed this view already in his paper from 1990, in which he interprets the prologue of Metamorphoses in the same fashion, arguing that the prologue-speaker is the 
partially because of the traditional authorial immortalitas. ${ }^{14}$ This is supported by the fact that the future immortality of the novel is adumbrated already in the Book II, where the author, the work itself, and the narrator blend together (2,12,5: mihi ... inquirenti multa respondit...; nunc enim gloriam satis floridam, nunc historiam magnam et incredundam fabulam et libros me futurum). ${ }^{15}$ This means that Madaurensis does not, in fact, pertain to Lucius' origin; therefore, the novel's unity is, in fact, not disrupted at all, as there is no literary metamorphosis of Lucius into Apuleius.

A deeper analysis of the objective changes has blurred the unambiguous perception of Lucius' metamorphosis, but the analysis of Lucius' feelings will refute even the metamorphosis itself.

The first evidence of this is Lucius' oscillation between an ass and a human. Despite the fact that he feels like a man trapped unwillingly in the shape of an ass $(3,26,1$ : quamquam perfectus asinus et pro Lucio iumentum, sensum tamen retinebam humanum), ${ }^{16}$ his behaviour identifies him with the ass several times and not always in a calculated way, especially when it comes to physical needs. He is not able to control his wild gluttony, not even when his life is imminently endangered $(4,22) \cdot{ }^{17}$ Right after he has performed the human ways of consuming food to a great fun of his master and to his own pleasure of tasting delicacies $(10,17)$, he gladly plunges into feeding himself with the green vegetation around (10,29,3 ff.). He also hungrily launches into eating up the roses supposed to transform him $(11,13,2:$... coronam, quae rosis amoenis intexta fulgurabat, avido ore susceptam cupidus promissi devoravi), despite having been admonished by Isis to pluck them very carefully, as if he kissed the hand of a priest (11,6,2: ... clementer velut manum sacerdotis osculabundus rosis decerptis pessimae mihique iam dudum detestabilis beluae istius corio te protinus exue). He fights back the attackers by kicking $(4,3,3 ; 7,19,3)$, and shitting $(4,3,7 ; 7,28,2)$; his fear is expressed by uncontrollable sweating $(11,7,1)$, while he conveys his sadness or despise with braying $(7,2,3 ; 8,29,4)$. But he also simultaneously forgets about his ass shape and reacts in a purely human way. For instance, in 4,6,1, he seeks to exercise a poetic depiction of a cave (res ac tempus ipsorum locorum speluncaeque illius, <quam> latrones inhabitabant, descriptionem exponere flagitat) and, at the same time, to persuade the readers about his

book itself; see Harrison (1990: pp. 507-513). Thus, Book XI, in fact, mirrors the first books and seals the unity of the whole work.

14 Cf. Hor. Carm. 2.20, 3.30 (Exegi monumentum aere perennius...); Epist. 1.20; and Ov. Met. 15.879 (Iamque opus exegi, quod nec Iovis ira nec ignis / nec poterit ferrum nec edax abolere vetustas). The last word of the novel obibam may be a pun on Ovid's concluding vivam; cf. Apuleius' intertextual word-play in note 12. For Apuleius' claim for literary immortality, cf. Smith (1972: pp. 530-534); Graverini (2005: pp. 225-250).

15 Cf. also Swain (2001: pp. 55-63).

16 This may be inspired by the well-known Homeric story of Ulysses and his companions who were transformed into pigs by Circe but still retained their human nature (Hom. Od. 10,239). Cf. Ov. Met. 3,203 in which Actaeon keeps his human mind even after his transformation: mens tantum pristina mansit. It is worth noting here that, just like Lucius, Actaeon calls this fate upon himself by his curious behaviour (cf. Apul. Met. 2,4).

17 Lucius is unable to gain control of his dangerous gluttony even despite the fact that he is a captive of the robbers who repeatedly plan to kill him. Moreover, he himself reflects on its hazardous nature in Apul. Met. 14,22,6: Et quamquam prius cum essem Lucius, unico uel secundo pane contentus mensa decederem, tunc uentri tam profundo seruiens iam ferme tertium qualum rumigabam. 
manhood (nam et meum simul periclitabor ingenium, et faxo vos quoque, an mente etiam sensuque fuerim asinus, sedulo sentiatis), he is sorry about not having a stylus to write down the fairytale of Amor and Psyche (6,25,1: ... sed astans ego non procul dolebam mehercules, quod pugillares et stilum non habebam, qui tam bellam fabellam praenotarem $),{ }^{18}$ he refers to Homer $(9,13,5$ : priscae poeticae divinus auctor) on whom he draws when he wants to make literary use of his tough experiences $(9,13,6$ : et ipse gratas gratias asino meo memini), he is outraged by the unjust court sentences $(10,33)$, and even has sexual intercourse with a woman $(10,22)$.

Let us now excurse a little and state the abovementioned passage $9,13,5 \mathrm{f}$. in full:

\begin{abstract}
Apul. Met. 9,13,5: Nec inmerito priscae poeticae divinus auctor apud Graios summae prudentiae virum monstrare cupiens multarum civitatium obitu et variorum populorum cognitu summas adeptum virtutes cecinit. Nam et ipse gratas gratias asino meo memini, quod me suo celatum tegmine variisque fortunis exercitatum, etsi minus prudentem, multiscium reddidit.
\end{abstract}

While Homer's hero in the abovementioned passage 9,13,5 reached summam prudentiam with his peregrination, Lucius achieves only polymathic knowledge (expressed by the epithet multiscius) instead. Even though polymathy did not have negative connotations in the age of Second Sophistic (in contrast with the opinions of the philosophers and scholars of the previous periods), it surely sounded negatively in the context of Odyssean peregrination where it appeared. ${ }^{19}$ In fact, Lucius admits, with a delicate self-irony, that he, although yearning for prudentia (understood as a philosophical ideal), never achieved such wisdom as Ulysses who was prudens even before he set off for his journey. Thus, it can be regarded another feature of a "non-transformation".

Lucius' passivity, which makes him an "ass" even before the real transformation takes place, is another feature supporting the ambiguousness of his feelings. In other words, Lucius is being repeatedly harmed or constrained by other people without even attempting to defend himself effectively. As suggested by Smith, his self-esteem is lowered to that of an animal. ${ }^{20}$ When his friend and classmate Pythias, the present aedil in Hypatae, whom he meets accidentally, tramples down the fish he had for dinner to "punish" (in Pythias' words) the dishonest fish-seller, Lucius' only reaction is awe (1,25,5: his actis consternatus ac prorsus obstupidus...). Moreover, he constantly apologizes the behaviour of his unbearably penurious host Milo (2,3,3: 'absit, ... parens, ut Milonem hospitem sine ulla querela deseram...'; 7,3,1: ego ... crimine latrocinii in hospitem mihi carissimum postulabar) despite the fact that he does not offer him anything but words (1,26,5: evasi aliquando rancidi senis loquax et famelicum convivium somno, non cibo gravatus, cenatus solis fabulis...;

18 GCA VI, 25-32 (1981: p. 26, entry fabellam) suggest that this may be an allusion to the proverbial surdo narrare fabulam - see e.g. Hor. Ep. 2.1.199 f.: scriptores autem narrare putaret asello / fabellam surdo.

19 In his other works, however, Apuleius uses the adjective as a positive thing (Apul. Flor. 3: Apollo esset ... arte multiscius...; Apol. 31.2: ... Homerum, poetam multiscium...). Besides, his own polymathy is reflected in the diversity of his corpus (including the unpreserved works) as well as in his own self-presentation (Flor. 20.4-7: ego et alias creterras Athenis bibi ... Apuleius vester haec omnia novemque Musas pari studio colit...).

20 See Smith (1994: pp. 1593 f.). Regarding Lucius' passivity, cf. Relihan (2007: p. xvii) who regards Lucius' passivity as that of a victim. 
2,15,1: haec Milone diutine sermocinante tacitus ingemescebam...), scorns him for his belief in the divinations of a fraudulent fortune-teller Diophanes $(2,14,5)$, and even exposes him to the general amusement of his fellow citizens at the festival of Risus $(3,10 \mathrm{f}$.), at which he becomes completely paralysed (3,10,2: at ego ... fixus in lapidem steti gelidus nihil secus quam una de ceteris theatri statuis vel columnis). Furthermore, despite readers' expectations, Lucius remains the same "ass" even after goddess Isis grants him back his human shape. He again gets controlled by dreamy visions in which Isis appears to manifest her will to him and becomes a puppet of the interpretations negotiated by the cunning priests in her temple. We will get to this matter again later. Whereas Lucius as an ass, after all, managed to defend himself more or less successfully (he was able to kick, bite, escape, or shit on his enemies), as a man he completely succumbs to the will of others, as if the human shape tied up his hands and tongue. It might be objected that the transformed Lucius submits voluntarily, while Lucius the ass suffered injustice before re-transformation. However, Apuleius does not let readers come to such an upright conclusion - Lucius is far from assured of the initiation's purpose or of the intentions of the priests, though he obeys them in the end. On the contrary, this is a clear signal for readers that no transformation of this Lucius' attribute took place at all and that Lucius, even as an initiate, remains a powerless victim, this time, a victim of the cult.

Perhaps the central and most apparent characteristic of Lucius and the whole novel is a pathological curiositas. ${ }^{21}$ Lucius describes himself as too curious several times throughout the novel..$^{22}$ His curiosity gets him into trouble of becoming an ass ${ }^{23}$ and it stands also behind other preventable complications happening to him in his ass form. ${ }^{24}$ The

21 The topic is dealt with in much detail in Appendix II of GCA IX (1995: pp. 362-379), including the wellarranged overview of all references to curiosity (also those using adjectives other than curiosus) and an analysis of curiositas in the light of De Platone as well as from the narratological point of view.

22 Apul. Met. 1,2,2: Isto accepto sititor alioquin novitatis: 'Immo vero' inquam 'impertite sermonem non quidem curiosum sed qui velim scire vel cuncta vel certe plurima...'; 2,1,1: Ut primum nocte discussa sol novus diem fecit, et somno simul emersus et lectulo, anxius alioquin et nimis cupidus cognoscendi quae rara miraque sunt...; 2,2,1: Sic attonitus, immo vero cruciabili desiderio stupidus, nullo quidem initio vel omnino vestigio cupidinis meae reperto cuncta circumibam tamen.

23 Very soon, Lucius' curiositas surpasses its normal boundaries and becomes an obsession: Apul. Met. 2,6,1: At ego curiosus alioquin, ut primum artis magicae semper optatum nomen audivi, tantum a cautela Pamphiles afui ut etiam ultro gestirem tali magisterio me volens ampla cum mercede tradere et prorsus in ipsum barathrum saltu concito praecipitare. Festinus denique et vecors animi manu eius velut catena quadam memet expedio et 'Salve' propere addito ad Milonis hospitium perniciter evolo. Ac dum amenti similis celero vestigium, 'Age,' inquam, 'o Luci, evigila et tecum esto. Habes exoptatam occasionem, et voto diutino poteris fabulis miris explere pectus. '; 3,14,1: Tunc ego familiaris curiositatis admonitus factique causam delitiscentem nudari gestiens...; 3,19,2: ... sum namque coram magiae noscendae ardentissimus cupitor.

24 Apul. Met. 7,13,3: Et alias curiosus et tunc latronum captivitatis spectator optabam fieri; 9,12,2: At ego, quanquam eximie fatigatus et reflectione virium vehementer indiguus et prorsus fame perditus, tamen familiare curiositate attonitus et satis anxius, postposito cibo, qui copiosus aderat, inoptabilis officinae disciplinam cum delectatione quadam arbitrabar; 9,13,3: Nec ullum uspiam cruciabilis vitae solacium aderat, nisi quod ingenita mihi curiositate recreabar, dum praesentiam meam parvi facientes libere, quae volunt, omnes et agunt et loquuntur; 9,15,2: Quae saevitia multo mihi magis genuinam curiositatem in suos mores ampliaverat; 9,30,2: Accipe igitur quem ad modum homo curiosus iumenti faciem sustinens cuncta quae in perniciem pistoris mei gesta sunt cognovi; 9,42,2: Qua contentione et clamoso strepitu cognito, curiosus alioquin et inquieti procacitate praeditus asinus, dum obliquata cervice per quandam fenestrulam quidquam sibi vellet tumultus ille prospicere gestio...; 10,29,2: Ad dum 
pathological dimension of Lucius' curiosity is closely linked with another motif repeatedly occurring in the novel, namely his voyeurism. Due to his desire to observe, he puts himself in danger of being watched himself and, thus, becomes a part of the spectacle he is no longer able to control nor escape from it. This holds both for his human (see Lucius' exposure to mockery at the festival of Risus in 3,2-12) as well as his ass form, in which he sees things that are normally inaccessible to men and because of which he becomes the object of observation himself (see e.g. the scenes in which he becomes the source of demeaning amusement in 10,15 and 10,35).25

Therefore, the reader primarily expects the transformation of Lucius' attribute of curiosity at the end of the story. However, Apuleius does not conform to this - Lucius is not able to control his bad habit even after being "re-born" and dedicating himself to Isis. ${ }^{26}$ Not to say that, apart from the life lesson of becoming an ass, he may have also learned from the most extensive story of the novel about Amor and Psyche, which he heard among the robbers. Psyche, too, does not keep her temper (6,20,3: ... et repetita atque adorata candida ista luce, quanquam festinans obsequium terminare, mentem capitur temeraria curiositate et: 'ecce,' inquit, 'inepta ego diuinae formonsitatis gerula, quae nec tantillum quidem indidem mihi delibo uel sic illi amatori meo formonso placitura,' et cum dicto reserat pyxidem) and almost kills herself as well as the unborn baby she has conceived with Amor (6,21,3: 'Ecce' inquit 'rursum perieras, misella, simili curiositate'). Moreover, she does all these despite the fact that she was punished for her curiosity and her urge to see something she was not supposed to (i.e. she trespassed the boundaries by looking at her husband's face in 5,23,1: quae dum insatiabili animo Psyche, satis et curiosa, rimatur atque pertrectat et mariti sui miratur arma...) by wandering and fruitless search for her lost husband (5,23,1; 5,26-28). However, Lucius does not catch the message of this story, the fairy-tale arouses only his unrealizable literary ambitions (which reduces it to mere bellam fabellam: 6,25,1). ${ }^{27}$

Such narrow-mindedness is acceptable in an ass, although he claims to have a human soul, but Lucius does not change even after returning to his human body. He does not understand that his fate is a consequence of his own actions and puts all blame on Photis (11,20,5: ... cum me Photis malis incapistrasset erroribus...). The ambiguous sense of errores ("an error" or "wandering") may be of some significance here, as well. ${ }^{28}$ However, Lucius feels

ludicris scaenicorum choreis primitiae spectaculi dedicantur, tantisper ante portam constitutus pabulum laetissimi graminis, quod in ipso germinabat aditu, libens adfectabam, subinde curiosos oculos patente porta spectaculi prospectu gratissimo reficiens.

25 I.e. in a situation when he acts like a real gourmet, and when he indulges in sexual practices with a woman. For the concept of the observer and the observed one, see Slater (2003: pp. 85-100).

26 Cf. Relihan (2007: p. xxix). The curiosity remains but it is directed towards the real divinity, not to the parody of knowledge as before the transformation. Likewise, at the end of the story Apuleius expands, through the use of synonymic terminology, the working of curiositas even towards the reader, as if he was supposed to identify himself with the main protagonist; see Apul. Met. 11,23,5: Quaeras forsitan satis anxie, studiose lector, quid deinde dictum, quid factum... Sed parem noxam contraherent et aures et lingua $\{e\}$, <illicitae intemperantiae ista>, illae temerariae curiositatis.

27 Cf. Byrrhena's warning in Apul. Met. 2,5,3 and Lucius' inability to get the message, even despite its visual embodiment in the statue of Actaeon changing into a stag for watching Artemis $(2,4)$; cf. also note 16 . Neither Psyche nor Lucius learn from their mistakes and are saved only by external forces.

See Smith (2012: pp. 218 f.). Cf. 7,1,6: falsis amoribus ancillae Milonis animum inrepens. 
consistently negatively about Photis (cf. 7,14,2: Sed quas ego condignas Photidi diras devotiones inprecer, quae me formavit non canem, sed asinum...; 9,15,15: ... quanquam grauiter suscensens errori Photidis, quae me, dum auem fabricat, II perfecit asinum...). Moreover, he does so despite the fact that the priest who recapitulated his life immediately after his metamorphosis back into human shape, clearly marks Lucius' curiosity as the main cause of his misery $(11,15,1:$... sed lubrico virentis aetatulae ad serviles delapsus voluptates curiositatis inprosperae sinistrum praemium reportasti...). ${ }^{29}$

Thus, from this respect, Lucius submits to self-deceit and ends his peregrination without being improved. In this way, Apuleius deprives the story of a straightforward message. Nevertheless, this does not necessarily mean that he casts his readers into complete darkness. On the contrary, Lucius' "non-transformation" leads reader to the understanding that the religious conversion is not the intended outcome of the novel.

Furthermore, Apuleius does not confine himself to mere hints, as the reader gets assured of the abovementioned via the dreamy visions already spoken of. These accompany the whole Book XI (11,19,2: nec fuit nox una vel quies aliqua visu deae monituque ieiuna; see also 11,$20 ; 11,22,2 ; 11,26,2 ; 11,26,4$ f.) and undermine its religious dimension. Revelations in dreams were completely standard way of communicating things between gods and men and, as such, they raise no doubts. However, Apuleius treats dreams in a different way. Right before the story of Amor and Psyche is introduced, the old woman, who is a narrator of the story, placates the kidnapped girl frightened by a bad dream with the following words: Bono animo esto, mi erilis, nec vanis somniorum figmentis terreare. Nam praeter quod diurnae quietis imagines falsae perhibentur, tunc etiam nocturnae visiones contrarios eventus nonnumquam pronuntiant $(4,27,4)$. In addition, in the beginning of his wandering, Lucius listens to a story in which a dream showed itself to be even malicious (Socrates' tale in 1,6-19). Despite all these, he still bases his whole existence on dreams (11,27,1: ac dum religiosum scrupulum partim apud meum sensum disputo, partim sacratorum consiliis examino, novum mirumque plane comperior...). He believes priests and their interpretations of dreams, which are, of course, convenient for themselves only; in 11,28,2, he can even be regarded a victim of black-mailing: ergo duritia paupertatis intercedente, quod ait vetus proverbium, inter sacrum ego et saxum positus cruciabar, nec setius tamen identidem numinis premebar instantia. At the same time, he hesitates and doubts the legitimacy of initiation and the amount of costs connected to it for a conspicuously long time, and even questions the authority of priests and the pureness of their intentions $(11,29,1-3$, see especially the closure of the passage: '... nimirum perperam vel minus plene consuluerunt in me sacerdos uterque'; et hercules iam de fide quoque eorum opinari coeptabam sequius). The constant emphasis Lucius puts on the financial concerns of priests as well as the lack of funds necessary for the initiation ${ }^{30}$

29 Cf. Smith (1994: p. 1594).

30 Apul. Met. 11,22 f.: Indidem mihi praedicat, quae forent ad usum teletae necessario praeparanda. Ea protinus naviter et aliquanto liberalius partim ipse, partim per meos socios coemenda procuro...; 11,28,1-4: Ad istum modum desponsus sacris sumptuum tenuitate contra votum meum retardabar ... Iamque saepicule non sine magna turbatione stimulatus, postremo iussus, veste ipsa mea quamvis parvula distracta, sufficientem contraxi summulam. Et id ipsum praeceptum fuerat specialiter: 'An tu' inquit 'si quam rem voluptati struendae moliris, laciniis tuis nequaquam parceres: nunc tantas caerimonias aditurus impaenitendae te pauperiei cunctaris committere?' See also 
clearly indicate that no deep religious conversion takes place in Book XI, i.e. no transformation either. On the contrary, just like in the previous ten books, social maladies are being criticized, in this case, the venality of the hypocritical priests. Apuleius' exaggeration and criticism can be deciphered even indirectly. Two moments are key to this: first, a seeming detail that one of the priests is lame and, therefore, lacks the perfection required for this job in antiquity (11,27,5: is /i.e. quidam de sacratis/ ut agnitionem mihi scilicet certo aliquo sui signo subministraret, sinistri pedis talo paululum reflexo cunctabundo clementer incedebat vestigio); ${ }^{31}$ second, that Lucius wants to believe that the wrong interpretation of one of the dreams by the priest is correct, so he settles for the priest's interpretation promising the return of his slave named Candidus as actually meaning the return of his white horse. The deceitful interpretation of the dream in 11,20,1 (nocte quadam ... visus est mihi summus sacerdos ... respondisse ... servum etiam meum indidem /i.e. ex Thessalia/ supervenisse nomine Candidum), is confronted with the reality of 11,20,7 (quare sollertiam somni tum mirabar vel maxime, quod ... argumento servi Candidi equum mihi reddidisset colore candidum).

Finally, the metamorphosis does not happen as it should even when speaking of the construction of the plot. We assume that the supposed break between Book X and XI is not as distinctive as it is sometimes suggested. Lucius does not bottom out completely to be saved by Isis; contrariwise, he seems not to be aware of his situation at all - he feeds himself recklessly and enjoys the spectacle. Apart from that, the whole story ends only after two false closures, as Harrison plausibly argues: ${ }^{32}$ the reader looks forward to the conclusion twice in vain $(11,26,1-2 ; 11,28,6-29,1),{ }^{33}$ whereas the real climax comes only with the praise of the financial convenience of the initiation.

Lucius does not improve, he was an ass before his physical transformation took place and stays the same even after it. He does not comprehend what caused his suffering and does not learn from it. ${ }^{34}$ Although he regards curiosity his essential attribute and can

Harrison (2000: p. 245) who states eight different references to the expensiveness of the initiation; and Murgatroyd (2004: p. 321) who adds further examples of this.

31 While the lameness of the priest lifts a weight from Lucius' heart (11,27,5: sublata est ergo ... ambiguitatis tota caligo...), because it enables him to recognize the priest easily (according to his dream from the night before), the reader perceives this passage differently - either as ironizing or, at the least, ambiguous. See Laes \& Goodey \& Rose (2013: p. 9). Although the ancient primary sources on physical disabilities and their social consequences are scarce, it may be assumed that especially pastophorus, a low-grade priest whose job was to carry the sacred items, should not have been lame, as it would have been a serious obstacle to the ideal of symmetry required. Cf. Gell. N.A. 4,2, in which Gellius discusses the difference between the morbosus and the vitiosus slave, including the defects of blindness and lameness, and states the social consequences of physical defects for slaves. Last, but not least, the logic of the plot itself implies that physical beauty marked by symmetry is a necessary prerequisite not only for one's successful career, but also for one's intellectual skills. See also the Antonine ideal of symmetrical harmony in note 3 .

32 Harrison (2000: pp. 245 ff.).

33 Apul. Met. 11,26,1-2: ... tandem digredior et recta patrium larem reuisurus meum post aliquam multum temporis contendo. Paucisque post diebus deae potentis instinctu raptim constrictis sarcinulis, naue conscensa, Romam uersus profectionem dirigo...; 11,28,6-29,1: Quae res summum peregrinationi meae tribuebat solacium nec minus etiam uictum uberiorem subministrabat ... Et ecce post pauculum tempus inopinatis et usquequaque mirificis imperiis deum rursus interpellor et cogor tertiam quoque teletam sustinere.

34 But, unlike the Greek Loukios, he feels shame after his re-transformation, see Apul. Met. 11,14,4: velamento me naturali probe muniveram. See also Keulen (2015: pp. 29-55) who considers shame to be one of the 
introspect its risks, he does not admit that it was the true reason of his transformation and blames Photis for everything that has befallen him. Instead of contemplation and absolute dedication, his initiation is associated with constant stress on the costs related as well as on its financial profit and convenience. Based on the above-said arguments, we assume that the novel cannot be interpreted as a religious message.

What, then, can be drawn from the abovementioned findings as to the interpretation of the whole novel? If Apuleius' novel does not convey a profound religious statement and if its significance does not lie in the preparation for the climax of emendation and religious initiation of an individual, what can be said about it? Are Metamorphoses a mere sophistic pun of an Antonine intellectual of the $2^{\text {nd }}$ century CE, a display of Apuleius' excellent literary knowledge and skill designed only for readers' entertainment? The answer to all abovementioned questions is no. Apuleius deliberately blends seriousness with joke and irony, truth with deceit and self-delusion. He intentionally arouses reader's suspense and feeling of discrepancy, even a sense of absurdity and he does so completely in agreement with the Platonic teaching ${ }^{35}$ whose advocate he regarded himself to be. It must be kept in mind that, according to Platonism, doubt is the first step to knowledge. ${ }^{36}$

To conclude, Metamorphoses neither hide a religious message ${ }^{37}$ nor is it an aimless sophistic show-off. Apuleius teaches his readers to distinguish truth from deceit, to apply their common sense, revise the external influences, plainly, to look at the world with Apuleius' own, Voltaire-like eyes...

Stephen Harrison concludes his monograph with Apuleius' appeal to the reader expressed in his prologue: Lector intende, laetaberis $(1,1)$, while emphasizing the amusing nature of the novel. Despite the fact that the novel can surely be enjoyed even by the readers who do not conceive all subtleties nor decipher all hints of the author, we are convinced that Apuleius means intende as a necessary step towards laetaberis. In other words, Apuleius wrote the novel primarily for an enlightened and thoughtful reader, or, as he himself puts it, for lector scrupulosus $(9,30,1$; cf. also 11,23,5: studiose lector). This, at

gestures (together with e.g. sobbing and rubbing his face at the feet of Isis' statue, parading his baldness, etc.) pointing to Lucius' new moral and religious spirit. However, we assume that even though an outward change certainly takes place and can be considered successful on superficial level, there is no inner metamorphosis of Lucius whatsoever; thus, we do not conform to the religious reading of the Isis-book.

35 For the link between Apuleius' Metamorphoses and Platonic dialogues, see Dowden (2006: pp. 42-58). As for the other possible philosophical influences on the novel, see Van der Stockt (2012: pp. 168-182) and Finkelpearl (2012: pp. 183-201) on Plutarch; Graverini (2012: pp. 86-106) on Stoicism and Pythagoreism. Most recently, the novel has been seen in the context of Second Sophistic as a part of Apuleius' self-presentation and Gesamtprojekt, 'the total work of philosophy' displaying both Apuleius' rhetorical versatility and his effort to present himself as a philosopher, as suggested in GCA XI (2015: p. 5). The cultural-historical approach is now widely spread, e.g. in Tilg (2014); Bradley (2012); Riess (2008); Keulen \& Lee \& Finkelpearl \& Graverini (2014).

36 As noted e.g. by Graverini (2006: pp. 86-110, 107).

37 Second Sophistic and the period of the $2^{\text {nd }}$ century CE was, among other things, remarkable for the increased interest of educated elites in local cults, rituals, and religiosity, in general. Cf. Plut. De Iside et Osiride. The religious tone of Book XI, thus, did not have to convey any deeper religious message - the reader is not expected to become an initiate or to have a profound knowledge of the cult. The references to the rituals of Isis' cult are depicted in close connection to the Roman imperial cult (see Apul. Met. $11,17,3)$, while Rome is called sacrosancta ista civitas $(11,26,2)$. 
the same time, does not rule out Apuleius' ambition to reach as wide as possible readership. As most of the literary masterpieces, Metamorphoses is a deliberately multi-layered novel providing readers with several levels of understanding. The level reached depends exclusively on the intellectual qualities of a particular reader. ${ }^{38}$

Therefore, the most important message for those about to read the novel is that the greatest pleasure from reading the piece comes only with clever judgment.

\section{Bibliography}

Bradley, K. (2005). Apuleius and Carthage. Ancient Narrative, 4, 1-29.

Bradley, K. (2012). Apuleius and Antonine Rome: Historical Essays. Toronto: University of Toronto Press.

Coarelli, F. (1989). Apuleio a Ostia? Dialoghi di Archeologia, 7, 27-42.

Dowden, K. (2006). A Tale of Two Texts: Apuleius' sermo Milesius and Plato's Symposium. In W. H. Keulen, R. R. Nauta, \& S. Panayotakis (Eds.), Lectiones Scrupulosae. Essays on the Text and Interpretation of Apuleius' Metamorphoses in Honour of Maaike Zimmerman (Ancient Narrative, Suppl. 6; pp. 42-58). Groningen: Barkhuis.

Evans, E. C. (1941). The Study of Physiognomy in the Second Century A.D. Transactions and Proceedings of American Philological Association, 72, 96-108.

Finkelpearl, E. (2004). The Ends of the Metamorphoses (Apuleius' Metamorphoses 11.26-11.30).

In M. Zimmerman, \& R. van der Paardt (Eds.), Metamorphic Reflections: Essays Presented to Ben Hijmans at his $75^{\text {th }}$ Birthday (pp. 319-342). Leuven: Peeters.

Finkelpearl, E. (2012). Egyptian Religion in Met. 11 and Plutarch's DIO: Culture, Philosophy, and the Ineffable. In W. Keulen, \& U. Egelhaaf-Gaiser (Eds.), Aspects of Apuleius' Golden Ass. A Collection of Original Papers. Volume III: The Isis-Book (pp. 183-201). Leiden-Boston: Brill.

Foerster, R. (Ed.). (1893). Scriptores physiognomonici graeci et latini (2 vols.). Leipzig: Teubner.

Gianotti, G. F. (1986). Romanzo e ideologia. Studi sulle Metamorfosi di Apuleio. Naples: Liguori.

Graverini, L. (2005). A Booklike Self. Ovid and Apuleius. In D. Nelis (Ed.), Aetas Ovidiana? (Hermathena, 177-178, 2004-2005; pp. 225-250). Dublin: University of Dublin.

Graverini, L. (2006). An Old Wife's Tale. In W. H. Keulen, R. R. Nauta, \& S. Panayotakis (Eds.), Lectiones Scrupulosae. Essays on the Text and Interpretation of Apuleius' Metamorphoses in Honour of Maaike Zimmerman (Ancient Narrative, Suppl. 6; pp. 86-110). Groningen: Barkhuis.

Graverini, L. (2012a). Prudentia and Providentia: Book XI in Context. In W. Keulen, \& U. EgelhaafGaiser (Eds.), Aspects of Apuleius' Golden Ass. A Collection of Original Papers. Volume III: The Isis-

38 The fact that some Apuleius' contemporaries and later authors criticized the novel for being a frivolous and low piece of literature may, thus, be paradoxically ascribed to their own superficial and shallow reading of the novel; see e.g. Hist. Aug. Clod. Alb. 12.12: maior fuit dolor, quod illum pro litterato laudandum plerique duxistis, cum ille neniis quibusdam anilis occupatus ... inter milesias Punicas Apulei sui et ludicra literaria consenesceret. For the discussion of this matter, see also Graverini (2012: pp. 198-200) who supposes that Apuleius had a wide spectrum of readers, from those versed enough to appreciate his allusions to those who read the novel superficially only to kill time. To support this argument, he compares Metamorphoses to today's novel The Name of the Rose by U. Eco. Similarly, also Gianotti (1986: pp. 107 ff.). For the discussion of the same problem in Apuleius' Florida, see Bradley (2005). 
Book (pp. 86-106). Leiden-Boston: Brill.

Graverini, L. (2012b). Literature and Identity in the Golden Ass of Apuleius (Transl. B. T. Lee). Columbus: The Ohio State University Press.

Griffiths, J. G. (Ed.). (1975). Apuleius of Madauros. The Isis-Book (Metamorphoses, Book XI). Leiden: Brill. Harrison, S. J. (1990). The Speaking Book: The Prologue to Apuleius' Metamorphoses. The Classical Quarterly, 40(2), 507-513.

Harrison, S. J. (2000). Apuleius: A Latin Sophist. Oxford: Oxford University Press.

Helm, R. (Ed.). (2001). Apuleius: Metamorphoseon Libri XI. (3. ed.; Bibliotheca scriptorum Graecorum et Romanorum Teubneriana). Monachii et Lipsiae: K. G. Saur.

Hildebrand, G. F. (1842). (Ed.). L. Apuleii Opera Omnia. Vol. 1: Prolegomena et Metamorphoseon libros contingens. Leipzig: Teubner.

Keulen, W. H. (2006). Ad amussim congruentia: Measuring the Intellectual in Apuleius. In W. H. Keulen, R. R. Nauta, \& S. Panayotakis (Eds.), Lectiones Scrupulosae. Essays on the Text and Interpretation of Apuleius' Metamorphoses in Honour of Maaike Zimmerman (Ancient Narrative, Suppl. 6; pp. 168-202). Groningen: Barkhuis.

Keulen, W. H. (2015). Lubrico virentis aetatulae: Lucius as Initiate (Metamorphoses Book XI). In S. Harrison (Ed.), Characterization in Apuleius' Metamorphoses: Nine Studies (pp. 29-55). Newcastle upon Tyne: Cambridge Scholars Publishing.

Laes, Ch., Goodey, C. F., \& Rose, M. L. (2013). Approaching Disabilities a capite ad calcem: Hidden Themes in Roman Antiquity. In Ch. Laes, C. F. Goodey, \& M. L. Rose (Eds.), Disabilities in Roman Antiquity: disparate bodies a capite ad calcem (Mnemosyne Supplements, 356, pp. 1-15). Leiden: Brill.

Lee, B. J., Finkelpearl, E., \& Graverini, L. (2014). Apuleius and Africa. New York-London: Routledge. Murgatroyd, P. (2004). The ending of Apuleius' Metamorphoses. The Classical Quarterly, 54, 319-321.

Perry, B. E. (1967). The Ancient Romances: A Literary-Historical Account of their Origins. Berkeley-Los Angeles: University of California Press.

Relihan, J. C. (2007). Introduction: The Whole vs. the Parts. In Apuleius. The Golden Ass: Or, A Book of Changes (pp. xxvi-xxxi). Indianapolis-Cambridge: Hackett Publishing Company.

Rohde, E. (1885). Zu Apuleius. Rheinisches Museum, 40, 66-113.

Riess, W. (2008). Paideia at Play: Learning and Wit in Apuleius. Groningen: Barkhuis.

Slater, N. W. (2003). Spectator and Spectacle in Apuleius. In S. Panayotakis, Z. Zimmerman, \& W. Keulen (Eds.), The Ancient Novel and Beyond (pp. 85-100). Leiden: Brill.

Smith, W. S. (1972). The narrative voice in Apuleius' Metamorphoses. Transactions and Proceedings of the American Philological Association, 103, 513-534.

Smith, W. S. (1994). Style and character in The Golden Ass: suddenly an opposite appearance. In H. Temporini (Ed.), Aufstieg und Niedergang der Römischen Welt: Geschichte und Kultur Roms im Spiegel der neueren Forschung (II.34.2., pp. 1575-1599). Berlin: De Gruyter.

Smith, W. S. (2012). An Author Intrudes into His Narratives: Lucius 'Becomes' Apuleius. In W. Keulen, \& U. Egelhaaf-Gaiser (Eds.), Aspects of Apuleius' Golden Ass. A Collection of Original Papers. Volume III: The Isis-Book (pp. 202-219). Leiden-Boston: Brill.

Swain, S. (2001). The Hiding Author: Context and Implication. In A. Kahane, \& A. Laird (Eds.), A Companion to the Prologue of Apuleius' Metamorphoses (pp. 55-63). Oxford: Oxford University 
Press.

Swain, S. (2007). Polemon's Physiognomy. In S. Swain (Ed.), Seeing the Face, Seeing the Soul: Polemon's Physiognomy from Classical Antiquity to Medieval Islam (pp. 125-201). Oxford: Oxford University Press.

Tatum, J. (1982). Apuleius. In T. J. Luce (Ed.), Ancient Writers: Greece and Rome (pp. 1099-1116). New York: Scribner.

Tilg, S. (2014). Apuleius' Metamorphoses. A Study in Roman Fiction. Oxford: Oxford University Press.

Van der Stockt, L. (2012). Plutarch and Apuleius. Laborious Routes to Isis. In W. Keulen, \& U. Egelhaaf-Gaiser (Eds.), Aspects of Apuleius' Golden Ass. A Collection of Original Papers. Volume III: The Isis-Book (pp. 168-182). Leiden-Boston: Brill.

Van Oudendorp, F. (1786). Apuleii Opera Omnia I: Metamorphoseon Libri XI. Leiden: van der Eyk en Vygh.

Winkler, J. J. (1985). Auctor E Actor. A Narratological Reading of Apuleius' The Golden Ass. Berkeley et al.: University of California Press.

Wittmann, W. (1938). Das Isisbuch des Apuleius. Untersuchungen zur Geistesgeschichte des 2. Jahrhunderts (Forschungen zur Kirchen- und Geistesgeschichte, 12; originally Univ. Berlin, Diss. 1937). Stuttgart: Kohlhammer.

Doc. Mgr. Katarina Petrovićová, Ph.D. / petrovic@mail.muni.cz

Department of Classical Studies

Masaryk University, Faculty of Arts

Arna Nováka 1, 60200 Brno, Czech Republic

Mgr. Natália Gachallová / 261004@mail.muni.cz

Department of Classical Studies

Masaryk University, Faculty of Arts

Arna Nováka 1, 60200 Brno, Czech Republic 